\title{
Iran and the Caucasus: Maintaining Some Pragmatism
}

\author{
Mohammad-Reza Djalili ${ }^{1}$
}

From Iran's viewpoint, the Caucasus is not totally foreign territory. This perception is even more particularly true with regard to Transcaucasia, situated in the south of the Caucasus and closer to Iran's current borders. Since ancient times and up to the nineteenth century, this region was on numerous occasions a part of the Iranian "realm," at times for very long periods. The Iranian presence in the Caucasus was for centuries challenged in turn by the Greeks, Romans, Arabs, Turks, and Russians. The latter put an end to the Persian monarchic presence through a policy of gradual penetration. It was during the reign of the Qadjar Dynasty (1785-1925) that Iran definitively lost its Caucasian dependencies to Russia?

The collapse of the Soviet Union in 1991, along with the achievement of independence by the states of the South Caucasus and Central Asia, has considerably modified the geopolitical environment of Iran that is the only state, other than Russia, that shares common borders with countries situated both to the west and east of the Caspian Sea. Surprised by the sudden demise of the USSR, Tehran has been forced to hastily set up a policy in regard to this new situation. This policy has gradually taken shape around several key concerns: maintaining the country's security and territorial integrity, developing bilateral and multilateral economic relations, and emphasizing the advantages that Iran's geographical position offers for transit to landlocked countries. In order to reach its objectives and at the same time to restore its image in the international arena, Tehran has opted from the beginning for a cautious and rather pragmatic approach, setting aside some of the ideological preoccupations inherent in a revolutionary and religious regime. Moreover, the authorities of the Islamic Republic of Iran decided to conduct their policy in these two directions in close collaboration with Russia. This choice simultaneously reflected Tehran's desire to pursue a policy in close collaboration with Moscow, as it had done since the beginning of the Islamic revolution, as well as its concern to not cut itself off from its main supplier of arms and military equipment. In fact, Iran had no interest in hurting Russia's feelings and in thereby thwarting one of its main objectives: the diminishment of its international isolation.

In Transcaucasia, the country with which Iran has the longest borders is Azer-

\footnotetext{
${ }^{1}$ Mohammad-Reza Djalili is a Professor at the Graduate Institute of International Studies and at the Graduate Institute of Development Studies in Geneva.

${ }^{2}$ M.H. Ganji, "The historical development of the boundaries of Azerbaijan," in The Boundaries of Modern Iran, edited by Keith McLachlan (London: UCL Press, 1994), 37-46.
} 
baijan. ${ }^{3}$ Moreover, as the only Transcaucasian state located along the Caspian Sea, Azerbaijan also shares maritime borders with Iran. Furthermore, both countries share many historical, cultural, and religious affinities. A significant portion of the population of Iran also speaks Azeri Turkish. There are more Azeris in Iran than in the Republic of Azerbaijan, and Azeris in Iran do not constitute a marginal minority; rather, they represent a major constituency of the country and, as such, they are well represented in all the state, military, economic, and, of course, clerical spheres. ${ }^{4}$ From a religious point of view, the two countries both have Shiite majorities. In addition, their common history, rooted in pre-Islamic times and the Zoroastrian religion, the existence in Azerbaijan of Farsi-speaking minorities, and other linkages should all tend toward the establishment of close ties between the two states. Yet this has not been the case. For ten years, their relations have been marked above all by a mutual distrust, to say the very least. The effects of this situation are serious and extend far beyond the framework of bilateral relations. They determine to a great extent Iran's relations with other Transcaucasian states, and their influence even goes beyond relations between Tehran and Ankara. Given this perspective, an examination of Iranian-Azerbaijani relations is an effective way to understand Iranian policy with respect to the entire Transcaucasian Region.

\section{Iran-Azerbaijan, or Cordial Disagreement}

On July 23, 2001, a military confrontation between Iran and Azerbaijan took place for the first time in the Caspian Sea. 150 kilometers southeast of Baku, an Iranian warship intercepted and forcibly expelled a boat that was conducting prospecting operations for the British Petroleum company, working under a mandate from the government of Azerbaijan. Before any military intervention occurred, Tehran sent out warnings to the British Petroleum boat and dispatched an Iranian military airplane to fly overhead. Baku adamantly denounced these actions as violations of its airspace and territorial waters. ${ }^{5}$ Some time afterwards, a squadron of the Turkish Air Force undertook training exercises in Azerbaijan while, on August 25, General Hussein Kivrikoglu, commander of the Turkish Army's headquarters, came to Baku for an official visit. These actions were described in the Turkish press as demonstrations of Turkey's support for Azerbaijan's cause, and they prompted Tehran to complain of Ankara's interference in bilateral Iranian-Azerbaijani relations. ${ }^{6}$

\footnotetext{
${ }^{3}$ In all, $611 \mathrm{~km}$, of which 432 are with the main territory and 179 are with the enclave of Nakhitchevan.

${ }^{4}$ The number of Iranians speaking Azeri Turkish is estimated to be $15 \%$ to $20 \%$ of the total population of the country. With the progress in alphabetization and urbanization, a significant part of this population is bilingual today. See Brenda Shaffer, "The Formation of Azerbaijani collective identity in Iran," Nationalities Papers 28:3 (2000), 449-477.

5 "Gunboat Diplomacy in the Caspian," The Estimate, August 2001.

${ }^{6}$ Michael Lelyveld, "Azerbaijan: Turkey Pursues Ambiguous Ties," Radio Free Europe / Radio

Liberty, August 28, 2001, http://www.rferl.org/nca/features/2001/08/28082001113441.asp
} 
This incident is an indication of the unrest and the climate of distrust that has prevailed for years in relations between Tehran and Baku. Even if events of this type have not had serious consequences (until now, at least), they clearly reflect the difficulties present in attempts at the normalization of relations between the two countries. What are the roots of this unrest?

Before considering any other issues, and without exaggerating their significance, it is important to acknowledge that ideological discrepancies exist between Tehran and Baku. Like Iran, Azerbaijan is a country with a majority Shiite population. But the Azeri state is a secular one, whereas Iran has been, since February 1979, an Islamic Republic. In the international arena, Baku has sought closer ties with the West and a rapprochement with NATO. It has just entered the Council of Europe, is developing its relations with the United States, maintains a good relationship with Israel, and considers itself very close to Turkey. Iran, as far as Azerbaijan is concerned, is hindered in its vision of the world by the stumbling block of its anti-American stance. It criticizes "the Great Satan's arrogance," conducts an anti-Israel policy in the Middle East, supports Palestinian demands, collaborates closely with Russia in Transcaucasia, and has had, since the middle of the 90s, "difficult" relations with Turkey.

These ideological discrepancies, in spite of Iran's general preference for a pragmatic approach, are at times the source of difficulties in relations between the two neighbors and a cause of their disagreements. Because of these divergent views, the two countries have chosen opposing strategies that sometimes undermine even their own interests. It would be a mistake for Azerbaijan to conduct a policy that ignores its geographic situation and, for Iran, it is neither necessary nor always beneficial to seek the support of Russia in its Caucasian policies. Moscow has taken advantage of Iran's isolation to reinforce first of all its own position in the region, and of course favors its own interests at the expense of Iran's.

Besides ideology, Iranians and Azeris have different points of view concerning the exploitation of hydrocarbon resources in the Caspian Sea. These differences are firstly of a juridical character. Azerbaijan is in favor of sharing offshore resources while transposing the modalities of international maritime law, applicable only in open seas, to an enclosed sea-the Caspian. This method gives a significant advantage to a country like Azerbaijan that, given the length of its coast, could then utilize an area of $80,000 \mathrm{sq}$. $\mathrm{km}$. Iran is against this solution that leaves at its disposal an area of only 44,000 sq. $\mathrm{km}$, and advocates instead the idea of moving the drilling for petroleum resources beyond the littoral zones, under the control of an international institution representing all the neighboring countries. In case this option is not chosen, Tehran proposes that a regime of equal sharing between the five littoral states be implemented. ${ }^{7}$ But another problem has appeared on the

\footnotetext{
${ }^{7}$ On the Caspian and hydrocarbons see Mohammad-Reza Djalili and Thierry Kellner, Géopolitique de la nouvelle Asie centrale (Paris: PUF, 2001), 179-225.
} 


\section{THE QUARTERLY JOURNAL}

horizon. In 1994, when Azerbaijan concluded a petroleum exploration agreement considered to be the "contract of the century" with an international consortium, it was initially expected that Iran would have a five-percent participation in this petroleum consortium. In April 1995, under the pressure of the United States, Azerbaijan expelled Iran from this market, provoking the anger of the Iranians. They openly criticized the policy of the Azerbaijani President Heydar Aliyev, although he was preferable to the Iranians than his more nationalist predecessor Ebulfez Elchibey. Since then, in spite of Iran's involvement in other Azerbaijani oil drilling projects, a new bone of contention has been added to the Iranian-Azeri issue. The incident of July 2001, noted above, confirms the persistence of unrest with respect to the Caspian Sea that has poisoned relations between the two neighbor states.

More fundamental is the climate of suspicion and mutual distrust that has affected the whole of Iranian-Azeri relations, which can be explained above all by the opposing visions the two neighbors have of their history and identity. The Iranian perception of Azerbaijan differs somewhat from that of the former Soviet Union (which remains more or less the self-perception held by the current leaders of the Azerbaijani Republic). For the Iranians, the northwest portion of their territory, squeezed between Turkey on the west, the former USSR on the north, and the Caspian Sea on the east, is administratively divided today into three provinces of Western, Central, and Eastern Azerbaijan. The application of the name "Azerbaijan" to the Turkish-speaking part of the Caucasus is recent. It dates back to 1918, when Turkish troops, under Nuri Pasha's command, occupied Baku on September 15 and reorganized the former provinces under the name of Azerbaijan in order to achieve the Ottoman objective of the time, which was the annexation of Iranian Azerbaijan and the territories situated to the north of Arax and populated by Muslims, generally Turkish-speaking, who were considered "Caucasian Tatars" by the Russians under the Tsarist empire. ${ }^{8}$ This territory was in fact named after the generic term "Arran," or according to the particular denomination of each of its districts or khanats: Shirvan, Bakou, Gandja, Nakhitchevan, Talesh, etc. The Iranians, however, stress the strong affinities that exist between the populations living on both sides of the Arax. To them, in spite of the use of the Turkish language north of the Arax, from a cultural, historical, and social standpoint these populations belong to the Iranian world.

If Iranians perceive Iran as one of the most ancient states of Asia, the Azeri elite, most probably influenced by the Soviet approach to ethnic issues, has another vision of its history, and has developed a discourse around the myth of a "Greater Azerbaijan." From this perspective, there are two Azerbaijans, one in

\footnotetext{
${ }^{8}$ V. Minorsky, “Adharbaydjan," Encyclopédie de l'Islam (1960), vol.1, 197.

${ }^{9}$ Shireen Hunter, "Greater Azerbaijan: Myth or Reality?" in Mohammad-Reza Djalili, ed., Le Caucase Postsoviétique: la transition dans le conflit (Brussels: Bruylant, 1995), 115-142.
} 
the north - the former Soviet Republic — and another one in the south-Iranian Azerbaijan. Azerbaijan is seen as having been unfairly divided between the Iranians and the Russians, the latter having been challenged only after the collapse of the USSR. This vision is unacceptable to the Iranians, who see in this discourse a challenge to their territorial integrity, if not officially from the Azeri government, then at least from some Azerbaijani political circles. ${ }^{10}$ Iran's concern is even more justified, since this Pan-Azeri irredentism is sometimes combined with an anti-Iranian pan-Turkish philosophy that is not at all well received in Tehran.11

These opposing points of view constitute the background against which Iranian-Azerbaijani relations have developed, and do not serve to facilitate positive relations between the two countries. At times Tehran will accuse Baku of supporting separatist agitators in Iran. Baku, in turn, points up the existence of small Islamist groups manipulated by Iran. From time to time, protests are heard in Iran, saying that if Azerbaijan's populations want to join their "brothers from the south," Iran is ready to welcome them and to absorb their territory into the "Iranian motherland." These polite exchanges, even if they are not based on clearlyidentified facts-for the Republic of Azerbaijan does not have the means to actually threaten Iran's security, nor is it in Iran's interest to destabilize its neighborhave a harmful effect on bilateral relations and undermine the peace that should prevail in the normal development of interstate relations.

\section{Iran-Armenia, or Relations Between Very Good Neighbors}

Relations between Iran and the Armenian world as a whole go back to pre-Islamic times, and are indicated by the centuries-long presence of an Armenian community living in Iran. The number of Armenians in Iran has certainly decreased since the Islamic revolution, but they still constitute the most significant Christian community in the country today. ${ }^{12}$ In the middle of the 1970 s, the number of Armenians in Iran was estimated at around 250,000. Today, their number is around 150,000. Most of them live in cities such as Tehran, Ispahan, and Tabriz.13 Iran's relations with the Republic of Armenia, which shares a common border with Iran, must take these realities into account, but they are also influenced by other considerations. For Tehran, relations with Yerevan assume a particular importance given the existing difficulties in its relations with Baku. Moreover, the conflict between

\footnotetext{
${ }^{10}$ These are essentially small groups supporting the Popular Front of farmer-president Elchibey, individuals close to the Foundation for Azerbaijani Studies of Baku or affiliated with the World Congress of Azerbaijanis, a few activists of the Front of National Liberation of South Azerbaijan, etc.

${ }^{11}$ Touraj Atabaki, Azerbaijan: ethnicity and the struggle for power in Iran (London: I.B. Tauris, 2000).

${ }^{12}$ Eliz Sanasarian, Religious Minorities in Iran (Cambridge: Cambridge University Press, 2000), 34-40. See also Cosroe Chaqueri, ed., The Armenians of Iran (Cambridge, MA: Harvard Middle Eastern Monographs, 1998).

${ }^{13}$ Eliz Sanasarian, op cit., 36-37.
} 
Armenia and Azerbaijan concerning Nagorno-Karabakh that lasted several years along its borders (and may one day start up again), worries Iran, even though this conflict has allowed Iran to attempt mediation and thus to play a stronger political role in Transcaucasian affairs. ${ }^{14}$ Armenia, for its part, trapped between Turkey and Azerbaijan — both of whom it considers hostile - and an unstable Georgia, seeks to reinforce its ties to its large southern neighbor in order to ameliorate both its geographical and political constraints as an enclave. The objective conditions are therefore favorable for Christian Armenia and the Islamic Republic of Iran to get along and closely collaborate, despite their religious and ideological differences.

If the Armenians see in Iran a power capable of counterbalancing the activities of Turkey in Transcaucasia, and with whom they have neither historical nor territorial differences, the Iranians for their part also consider Armenia a buffer to Turkish influence on the northwest borders of their country and even, on some level, in Central Asia, where many Armenians live. ${ }^{15}$ Moreover, through establishing close ties with Yerevan, Tehran is without doubt seeking to win support among the Armenian diaspora in Europe, Russia, and the United States. Having said that, Iran's rapprochement with Armenia allows the consolidation of an informal alliance between Russia and Iran, a country with which Tehran shares common views concerning its Caucasian policy.

Iran's relationship with Armenia has also had as a consequence the development of bilateral economic relations between the two states. Iran has become the most significant trading partner of Armenia, and ground and air communication routes between the two countries have clearly improved during recent years. Along with the exportation of Iranian consumer goods comes the supply of oil, gas, and electricity. In fact, in November 2001, the two governments signed a draft agreement for the importation of Iranian and Turkmen gas through Iranian territory. The implementation of this project could lead to a significant mutual dependence between the two neighboring countries.

\section{Iran-Georgia: A More Difficult Cooperation}

In contrast to Azerbaijan and Armenia, Georgia does not share any common borders with Iran, but several considerations motivate the two countries to get along and to cooperate. In its policy regarding Transcaucasia, Iran cannot ignore Georgia. In return, Georgia cannot ignore Iran, since it needs to diversify its regional and international relations, most notably to counterbalance Russian influence. Moreover Georgia, being the only Transcaucasian State with a maritime coast on the open sea, must conduct a policy that will maximize the value of this asset, while turning its territory into a nerve center for communications and transportation. Such a perspective does not leave Iran indifferent, as they can envision the

\footnotetext{
${ }^{14}$ Abdollah Ramezanzadeh, "Iran's Role as a Mediator in the Nagorno-Karabakh Crisis," in Contested Borders in the Caucasus, edited by Bruno Coppiters (Brussels: VUB Press, 1996).

${ }^{15}$ Gayane Novikova, “Armenia and the Middle East," Meria 4:4 (December 2000), 60-66.
} 
possibility of laying out a transit route via Armenia or Azerbaijan in order to access the port of Poti on the Black Sea. Nonetheless, economic and commercial relations between the two countries have developed rather well in recent years.

The Iranian-Georgian relationship rests on political, economic, and geopolitical considerations. This last aspect cannot be mentioned without including the Chechen conflict that has been taking place along the northern border of Georgia and has had strong repercussions in this country. ${ }^{16}$ The Iranian policy towards this conflict is in contradiction with the constitutional principles of the Islamic Republic, which hold that the Iranian regime must extend help to all Muslim brothers fighting for their freedom. In the case of the Chechen conflict, Iran has shown its penchant for realpolitik, its selective approach to the Islamic "causes" that do or do not deserve its involvement. Even if, during a part of this conflict, from 1997 to 2000, the Iranian government, as president of the Organization of the Islamic Conference (OIC), did show some interest in the Chechen conflict, Iran preferred to sacrifice the interests of believers and chose to maintain its good relations with Russia, its main provider of military equipment and nuclear technology ${ }^{17}$ From this approach, it becomes evident that Tehran cannot politically support the position of Tbilisi in the face of pressures from Moscow that exhort Georgia toward more cooperation in the Russian fight against the Chechen rebellion.

The arrival, at the end of February 2002, of a number of American military advisers in Georgia in order to help the Tbilisi government in its fight against terrorism in the gorges of Pankisi, where the presence of members of the Al-Qaeda network has been reported, may disturb the climate of bilateral Iranian-Georgian relations. In effect, after the "installation" of Americans in Afghanistan and in several bases in Central Asia, the Iranians are worried about the "encirclement" of their territory by the American military forces already present in the Persian Gulf zone, and through NATO in Turkey. The prolonged presence of Americans in Georgia can only displease Tehran further.

\section{Perspectives}

The principles of Iranian policy in the Caucasus, despite some particularities, do not differ from those of the rest of its foreign policy. Since Khomeini's death, the orientations and guiding principles of this policy have gradually shifted. Once revolutionary and strongly affected by its ideology, Iran's foreign policy has become more pragmatic and conciliatory. Since Mohammad Khatami's ascent to the presidency in 1997, Tehran has abandoned a policy of confrontation for an approach based on dialogue and the pursuit of détente. However, these reforms of Iranian

\footnotetext{
${ }^{16}$ Le Monde, February 25, 2002.

${ }^{17}$ See A. William Samii, "Iran and Chechnya: Realpolitik at Work," Middle East Policy 8:1 (March 2001), as well as Svante E. Cornell, "Iran and the Caucasus: The Triumph of Pragmatism over Ideology," Global Dialogue, (Spring/Summer 2001), 80-92.
} 


\section{THE QUARTERLY JOURNAL}

diplomacy have some limits. ${ }^{18}$ The regime is still an Islamic Republic that remains reticent toward more secular Muslim regimes, distrustful toward Western democracies, and violently opposed to Israel and the United States. Anti-Americanism remains a leitmotif of Iranian policy. One can explain the resort to this discourse by the necessity for an Islamic regime like Iran's to keep a recurring theme presented as revolutionary and popular, the need to use the "Great Satan" as an outlet in the face of the failures and difficulties encountered by the Republic of the Mullahs, as well as by the stake that relations with Washington represent in internal quarrels between different Islamist factions intent on monopolizing power.

Concerning the new Transcaucasian states, Iranian policy naturally is adapting to the particular contexts affecting bilateral relations with each of them. But this policy fits more broadly, on one hand, into the specific framework of relations of Iran with Russia and Turkey, two other significant external actors in the regional dynamic, and on the other hand, into the global context of international policy.

A quick look at Turkish and Iranian strategies in Transcaucasia and in Eurasia more generally allows us to highlight their differences and above all to stress the way they influence each other. Thus, if the United States, Azerbaijan, and Israel are significant partners in Turkey's Eurasian policy, Iran bases its strategy on maintaining favored links with Russia, Greece, and Armenia. In order to conduct such a policy, Islamic Iran does not hesitate to encourage the Muslims of the former Soviet Union to get along with the Christian Orthodox. It condemns Chechen separatism, collaborates with Moscow to implement a peace process between Islamists and neo-communists in Tajikistan, and tends toward Armenian positions concerning the Nagorno-Karabakh conflict. Meanwhile, Turkey has established favored links to Azerbaijan (where some pan-Turkish factions do not hesitate to call for the concept of "one Nation, two States" regarding relations between the two), has established an alliance with Israel, and contributes to the emergence of an Ankara-Baku-Tel Aviv axis. Iran, for its part, is engaged in the formation of a counter-axis of Tehran-Athens-Yerevan. Thereby, each country seeks to prevent the other from reaching a hegemonic position in regional affairs. ${ }^{19}$

From an international point of view, the attacks of September 11, 2001 have had as a consequence a reinforcement of links between the United States, the Transcaucasian states, and Russia. Concerning the exploitation of Caspian oil and its transportation, a more peaceful climate prevails between America and Russia in this particular domain, a state of affairs that does not serve Iran's interests. Regarding Chechnya, from now on the Russians will present the war against the Chechens as a fight against terrorism. In December 2001, U.S. Secretary of Defense Donald Rumsfeld made a visit to Baku during which he declared that the

\footnotetext{
${ }^{18}$ Mohammad-Reza Djalili, Iran: l'illusion réformiste (Paris: Presses de sciences Po, 2001), 5976.

${ }^{19}$ About the Eurasian policy of Iran, see Nicolas K. Gvosdev, "Iran's Eurasian Strategy," Analysis of Current Events ACE 13:2 (May 2001), 1-5.
} 
United States wants to reinforce its military cooperation with Azerbaijan. A few days later, on January 11, 2002, President George Bush signed a decree canceling the legal provisions that prevented economic assistance to Azerbaijan that were made during the Nagorno-Karabakh conflict under the pressure of the Armenian lobby in the United States. At the end of February, the American military presence in Georgia was confirmed. If one adds to that the inclusion of Iran to the "Axis of Evil" in the State of the Union address by the American president, given on January 29, 2002, one can see that conditions for the implementation of Iranian policy in the Caucasus did not improve after September 11. 


\section{Bibliography}

A. Samii, William. "Iran and Chechnya: Realpolitik at Work." Middle East Policy 8, no. 1 (2001).

Atabaki, Touraj. Azerbaijan: Ethnicity and the Struggle for Power in Iran . London: I. B. Tauris, 2000.

Cornell, Svante E.. "Iran and the Caucasus: The Triumph of Pragmatism over Ideology." Global Dialogue (2001): 80-92.

Djalili, Mohammad-Reza, and Thierry Kellner. Géopolitique de la nouvelle Asie centrale. Paris: PUF, 2001.

Ganji, M.H.. "The historical development of the boundaries of Azerbaijan." In The Boundaries of Modern Iran. London: UCL Press, 1994.

Gvosdev, Nicolas K.. "Iran's Eurasian Strategy." Analysis of Current Events ACE 13, no. 2 (2001): 1-5.

Ramezanzadeh, Abdollah. Iran's Role as a Mediator in the Nagorno-Karabakh Crisis In Contested Borders in the Caucasus., 1996.

Sanasarian, Eliz. Religious Minorities in Iran . Cambridge: Cambridge University Press, 2000.

The Armenians of Iran . Cambridge, MA: Harvard Middle Eastern Monographs, 1998. 